\title{
INTEGRATED NUTRIENT MANAGEMENT (INM) FOR HYBRID MAIZE GROWN IN CALCAREOUS SOIL Kaleeswari, R.K. ${ }^{1}$, J. Prabakaran ${ }^{1}$, M.R. Latha ${ }^{1}$ and M.M. Mansour ${ }^{1,2}$ 1 Dept. of Soil Sci. and Agric. Chemistry, Tamil Nadu Agric. Univ., Coimbatore, Tamil Nadu, India. \\ 1,2 Soils Dept., Fac. of Agric., Mansoura Univ., Mansoura, Egypt.
}

\begin{abstract}
Field experiments were conducted at Research Farm of Tamil Nadu Agricultural University, Coimbatore, India for a period of three years (2007-2009) to find out the effect of integrated nutrient management on productivity of hybrid maize. Conjunctive use of $100 \% \mathrm{NPK}+5 \mathrm{t} \mathrm{ha}^{-1}$ poultry manure recorded significantly highest grain and stover yields. Integration of $100 \%$ NPK with FYM and micronutrients viz., zinc and iron recorded higher yield than the treatment that received $100 \% \mathrm{NPK}+$ poultry manure $+\mathrm{ZnSO}_{4}+\mathrm{FeSO}_{4}$. The lowest yield of $5637 \mathrm{~kg} \mathrm{ha}^{-1}$ was recorded in the treatment that received $100 \%$ NPK. The uptake of macronutrients by hybrid maize increased with increase in NPK levels. The organic carbon, available $\mathrm{N}$ and $\mathrm{K}$ status of soil improved due to the application of $100 \% \mathrm{NPK}+5 \mathrm{t} \mathrm{ha}^{-1}$ poultry manure while the available $P$ status was increased with $75 \% \mathrm{NPK}+5 \mathrm{t} \mathrm{ha}^{-1}$ poultry manure. The highest benefit : cost ratio (2.52) was obtained with the application of $100 \%$ NPK + $\mathrm{FYM}+\mathrm{ZnSO}_{4}+\mathrm{FeSO}_{4}$
\end{abstract}

Keywords: Integrated nutrient management (INM), NPK, Micronutrient, Organic manures, Maize, Calcareous soil.

\section{INTRODUCTION}

Integrated use of organics and inorganics improve the soil and crop productivity. The continuous use of micronutrient free high analysis NPK fertilizers in the intensive cropping system with reduced use of organic manures have resulted in the depletion of soil micronutrients (Singh 2007). Application of chemical fertilizers even in balanced amount does not sustain the soil health under continuous cropping where as inclusion of organic manures regulates the removal of nutrients, improve the physico-chemical properties of soil (Satish Chander and Tripathi, 2006).

Maize (Zea mays L.) is a nutrient exhaustive crop and hybrids varied in nutrient uptake indicating their nutrient use efficiency due to higher biomass production. Moreover, continuous cropping of hybrid maize might lead to the rapid depletion of mineral nutrients from soil unless appropriate nutrient inputs are supplied. Crop response to nutrition depends on balanced use of fertilizers. The decline in soil fertility due to imbalanced fertilizer use has been recognized as one of the most important factors limiting crop yields (Nambiar and Abrol, 1989). Hence, the present investigation was carried out to study the effect of integrated nutrient management (INM) on yield and nutrient uptake by hybrid maize in a calcareous soil. 


\section{MATERIALS AND METHODS}

Field experiments were carried out at the Research Farm of Tamil Nadu Agricultural University, Coimbatore $\left(11^{\circ} 0^{\prime} \mathrm{N}, 77^{\circ} 0^{\prime} \mathrm{E}\right)$ in winter seasons (October - December) for a period of three years (2007-2009) using hybrid maize ( $\mathrm{COH}(\mathrm{M}) 4)$ as test crop. The mean maximum and minimum temperature of this area varies between $35^{\circ} \mathrm{C}$ to $18^{\circ} \mathrm{C}$ with an average rainfall of $700 \mathrm{~mm}$. The initial soil sample from the experimental plot was analyzed for soil texture, bulk density, particle density, electrical conductivity and cation exchange capacity following standard procedures (Jackson, 1973). The soil of the experimental field was well drained, sandy clay loam, alkaline in reaction ( $\mathrm{pH} 8.17)$, EC $\left(0.54 \mathrm{dS} \mathrm{m}^{-1}\right)$, organic carbon $\left(7.70 \mathrm{~g} \mathrm{~kg}^{-1}\right.$ soil), Bulk density $\left(1.25 \mathrm{Mg} \mathrm{m}^{-3}\right.$ ), available nitrogen $182 \mathrm{~kg} \mathrm{ha}^{-1}$, available phosphorus $21.5 \mathrm{~kg} \mathrm{ha}^{-1}$ and available potassium $650 \mathrm{~kg} \mathrm{ha}^{-1}$ (Table 1). Ten treatments consisted of two levels of NPK (75\% and $100 \%)$ in combination with farmyard manure, poultry manure; zinc and iron were laid out in randomized block design with three replications as follows:

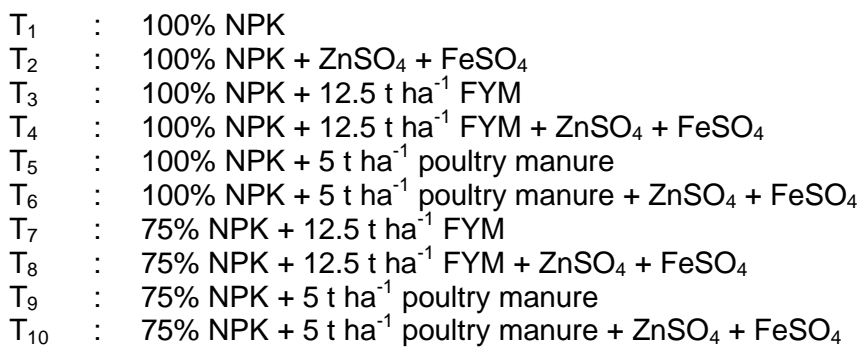

Table 1: Initial Soil characteristics of the experimental plot

\begin{tabular}{lll}
\hline Parameters & & Value \\
\hline Soil texture & & Sandy clay loam \\
Soil taxonomy & $\left(\mathrm{Mg} \mathrm{M}^{-3}\right)$ & Vertic Ustropept \\
Bulk density & $\left(\mathrm{Mg} \mathrm{M}^{-3}\right)$ & 1.25 \\
Particle density & $(\%)$ & 1.43 \\
Pore space & & 40.0 \\
$\mathrm{pH}^{*}$ & $\left(\mathrm{dS} \mathrm{m}^{-1}\right)$ & 8.17 \\
Electrical conductivity** & $\left.\left(\mathrm{cmol}^{*} \mathrm{p}^{+}\right) \mathrm{kg}^{-1}\right)$ & 0.54 \\
Cation exchange capacity & $\left(\mathrm{kg} \mathrm{ha}^{-1}\right)$ & 22.5 \\
Available N & $\left(\mathrm{kg} \mathrm{ha}^{-1}\right)$ & 182 \\
Available P & $\left(\mathrm{kg} \mathrm{ha}^{-1}\right)$ & 21.5 \\
Available K & $\left(\mathrm{g} \mathrm{kg}^{-1}\right)$ & 650 \\
Organic carbon & $(\%)$ & 7.70 \\
$\mathrm{CaCO}_{3}$ & $(\%)$ & 10.0 \\
\hline
\end{tabular}

* $\mathrm{pH}$ was determined in 1:2 soil-water suspension.

** EC was determined in 1:2 soil-water extract.

The $\mathrm{N}$ content in the manure samples was determined by micro kjeldahl method. Total $\mathrm{P}$ and $\mathrm{K}$ contents were extracted by digestion with diacid $\left(\mathrm{H}_{2} \mathrm{SO}_{4}: \mathrm{HClO}_{4}, 5: 2\right)$, the available $\mathrm{P}$ was estimated colorimetrically as vanado-molybophosphate yellow colour complex and available $\mathrm{K}$ was 
determined by flame photometer. Micronutrients in the diacid extract was analyzed (Table 2) by Atomic Absorption Spectrophotometer (Jackson, 1973). Nitrogen, phosphorus, potassium, $\mathrm{Zn}$ and Fe were applied in the form of urea, single super phosphate, muriate of potash, zinc sulphate and ferrous sulphate at $250,75,75,25$ and $50 \mathrm{~kg} \mathrm{ha}^{-1}$, respectively as per the blanket recommendation of Department of Agriculture, Government of Tamil Nadu. Organic manures were applied as basal dressing. The whole amount of phosphorus, potassium, $\mathrm{Zn}, \mathrm{Fe}$ and half quantity of $\mathrm{N}$ were applied as per treatment schedule at the time of sowing as basal and rest half of $\mathrm{N}$ was applied at the tasselling stage. Surface irrigation was given and other intercultural operations were carried out as given in Crop Production Guide (2005). At harvest stage, the grain and stover yield were recorded and samples were taken for N, P and K analysis (Piper, 1942). Also, the nutrient uptake by grain and stover were estimated. The post harvest soil samples were analyzed for soil $\mathrm{pH}$, electrical conductivity (Richards, 1954), organic carbon (Walkley and Black, 1934), available N (Subbiah and Asija, 1956), available P (Olsen et al., 1954), available K (Stanford and English, 1949) and DTPA extractable Zn and Fe (Lindsay and Norvell, 1978).

Table 2: Nutrient content of the organic manures used for the study.

\begin{tabular}{llcc}
\hline Parameters & & Farmyard manure & Poultry manure \\
\hline Total N & $(\%)$ & 0.14 & 1.96 \\
Total P & $(\%)$ & 0.19 & 0.29 \\
Total K & $(\%)$ & 0.10 & 0.10 \\
Total Fe & $\left(\mathrm{mg} \mathrm{kg}^{-1}\right)$ & 20.5 & 629 \\
Total Zn & $\left(\mathrm{mg} \mathrm{kg}^{-1}\right)$ & 23.2 & 58.0 \\
Total $\mathrm{Mn}$ & $\left(\mathrm{mg} \mathrm{kg}^{-1}\right)$ & 7.70 & 40.4 \\
Total Cu & $\left(\mathrm{mg} \mathrm{kg}^{-1}\right)$ & 12.9 & 22.7 \\
Organic Carbon & $(\%)$ & 6.60 & 12.3 \\
C:N ratio & & $47: 1$ & $6: 3$ \\
\hline
\end{tabular}

\section{RESULTS AND DISCUSSION}

\section{a. Gain and stover yields of hybrid maize}

The pooled data of three years trials presented in Table 3, revealed that the application of $100 \% \mathrm{NPK}+5 \mathrm{t} \mathrm{ha}^{-1}$ poultry manure recorded significantly highest grain and stover yields. This could be due to the balanced nutrition of crops supplied through inorganic fertilizers and poultry manure. Maize being nutrient exhaustive crop responds well to the balanced fertilization. The beneficial effect of poultry manure would be due to adequate nutrient supply during the decomposition of organic manure, enhanced mobilization of nutrients from the soil and soil microbial activities through the production of organic acids and improved soil physical conditions consequently led to the increased crop productivity. Similar results were also observed by Singh and Pathak (2003), Datt et al., (2003) and Jaggi (2007). It could also be attributed to the fact that, after decomposition and mineralization, the manures supplied available nutrients directly to plants and also had solubilizing effect on fixed form of nutrients (Sinha et al.,1981). 
Kaleeswari, R. K. et al.

Table 3: Grain and stover yields of hybrid maize.

\begin{tabular}{|c|c|c|c|}
\hline \multirow{2}{*}{ Treatments } & \multicolumn{2}{|c|}{ Yield $^{*}\left(\mathrm{~kg} \mathrm{ha}^{-1}\right)$} & \multirow{2}{*}{$\mathrm{B}: \mathrm{C}$ ratio } \\
\hline & Grain & Stover & \\
\hline $\mathrm{T}_{1}$ & 5637 & 8347 & 1.17 \\
\hline $\mathrm{T}_{2}$ & 6283 & 9337 & 2.14 \\
\hline $\mathrm{T}_{3}$ & 5784 & 8638 & 2.39 \\
\hline $\mathrm{T}_{4}$ & 6679 & 9996 & 2.52 \\
\hline $\mathrm{T}_{5}$ & 6985 & 10431 & 1.38 \\
\hline $\mathrm{T}_{6}$ & 6281 & 9158 & 2.12 \\
\hline $\mathrm{T}_{7}$ & 6506 & 9585 & 2.05 \\
\hline $\mathrm{T}_{8}$ & 6325 & 9390 & 2.34 \\
\hline $\mathrm{T}_{9}$ & 5749 & 8584 & 1.99 \\
\hline $\mathrm{T}_{10}$ & 6223 & 9207 & 2.11 \\
\hline SEd & 166 & 236 & - \\
\hline$C D(P=0.05)$ & 350 & 497 & - \\
\hline
\end{tabular}

* Pooled mean of three years.

The increase in grain yield treatment $T_{5}$ was on par with the yield obtained in treatment $\mathrm{T}_{4}$. The integration of $100 \%$ NPK with FYM and micronutrients resulted in increase in grain yield. The experimental soil was calcareous and hence the yield response to the micronutrient fertilization was also observed. Stover yield also followed the same trend.

The lowest yield of $5637 \mathrm{~kg} \mathrm{ha}^{-1}$ was recorded in the treatment that received $100 \%$ NPK. Integration of $100 \%$ NPK with FYM and micronutrients viz., $\mathrm{Zn}$ and $\mathrm{Fe}$ recorded higher yield than the treatment $\mathrm{T}_{6}$. This could be due to the presence of $\mathrm{CaCO}_{3}$ content $(10 \%)$ of poultry manure which neutralizes the organic acids produced during decomposition thereby limiting the availability of organic acids for dissolution of micronutrients (Mahimairaja et al., 1995 and Kaleeswari, 2009). Hence the yield response to micronutrients when applied with FYM was greater.

\section{b. Benefit : cost ratio}

For economic analysis, the benefit cost ratio $(B: C)$ was calculated by dividing the gross income by total expenditure $\left(R s . h^{-1}\right)$. The highest $\mathrm{B}: \mathrm{C}$ ratio was recorded in the treatment $\mathrm{T}_{4}(2.52)$ followed by $100 \% \mathrm{NPK}+\mathrm{FYM}$ (2.39). Though poultry manure application increased the grain and stover yields, due to the high cost of poultry manure as compared with FYM, B:C ratios were lower in the poultry manure treated plots (Table 3 ).

\section{c. Nutrient uptake}

The pooled data pertaining to $\mathrm{N}, \mathrm{P}$ and $\mathrm{K}$ uptake by grain and stover revealed that nutrient uptake in the treatments $T_{5}$ and $T_{4}$ were on par. This could be due to the increase of nutrient availability as well as higher dry matter production. The nutrients uptake was increased with increased of NPK levels (Fig. $1 \& 2$ ). These results are in concurrence with those reported by Adeli and Varco (2002) and Pervez et al., (2004) in cotton.

\section{d. Changes in soil nutrient status}

The electrical conductivity and $\mathrm{pH}$ were the highest in the treatment $\mathrm{T}_{10}$. This increase might be attributed to the addition of salts through application of increased doses of inorganics. These results are in accordance with the findings of Santhy et al., (1999). The highest organic carbon content was recorded in the treatment that received $T_{5}$. The increase in organic 
carbon content may be attributed to addition of organic materials and better root growth. These observations are in agreement with the findings of Sharma et al., (2005). The organic carbon contents were lower in the treatment that received only inorganic fertilizers. This could be due to the low organic carbon status of the experimental soil (Table 4).

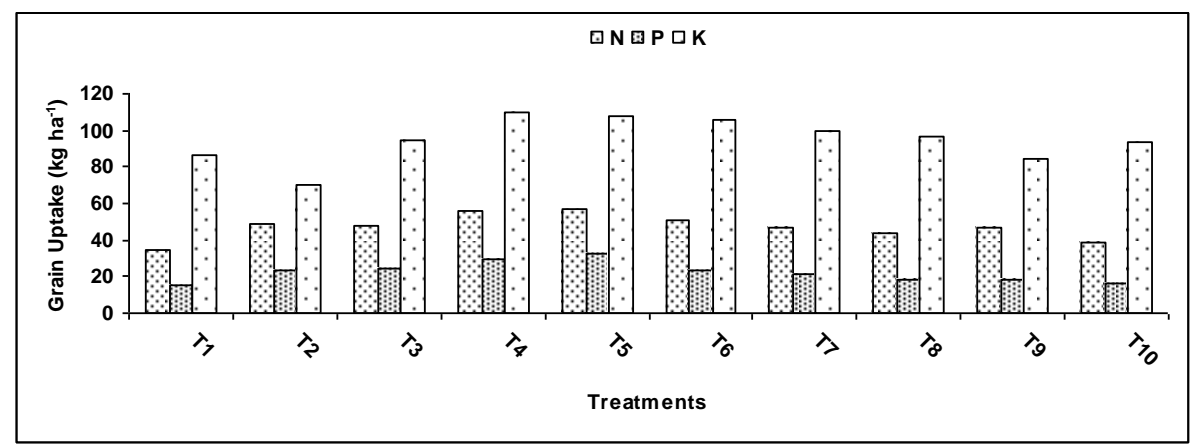

Fig. 1. Uptake of N, P and K by grain yield of hybrid maize.

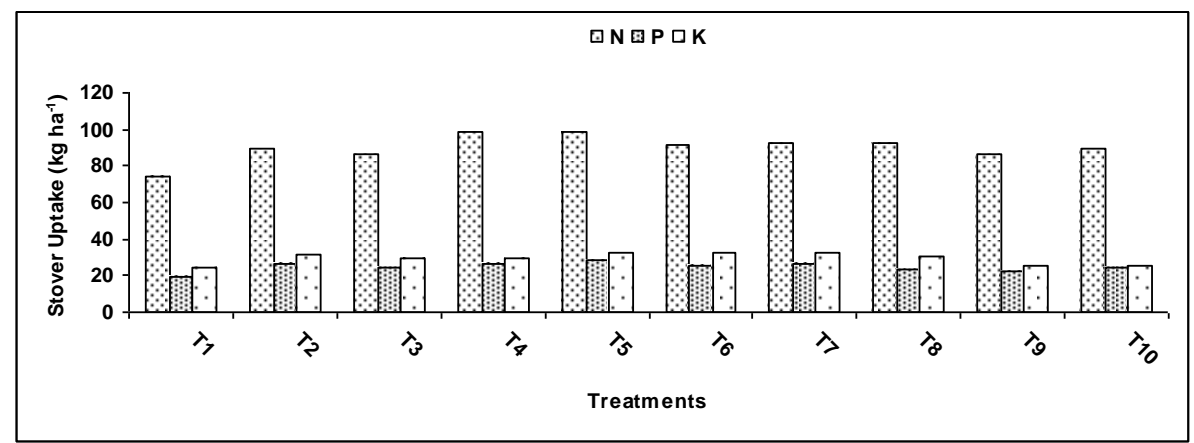

Fig. 2. Uptake of $\mathrm{N}, \mathrm{P}$ and $\mathrm{K}$ by stover yield of hybrid maize.

Table 4: Changes in pH, EC and organic carbon of the post harvest soil.

\begin{tabular}{|c|c|c|c|}
\hline Treatments & $\mathrm{pH}^{\star}$ & $E C\left(d S ~ m^{-1}\right)^{\star}$ & Organic carbon (\%) \\
\hline$T_{1}$ & 7.82 & 0.54 & 0.51 \\
\hline $\mathrm{T}_{2}$ & 7.81 & 0.78 & 0.57 \\
\hline $\mathrm{T}_{3}$ & 7.86 & 0.70 & 0.79 \\
\hline $\mathrm{T}_{4}$ & 8.06 & 0.25 & 0.69 \\
\hline$T_{5}$ & 8.02 & 0.66 & 1.30 \\
\hline $\mathrm{T}_{6}$ & 8.08 & 0.53 & 1.01 \\
\hline $\mathrm{T}_{7}$ & 7.90 & 0.81 & 0.95 \\
\hline $\mathrm{T}_{8}$ & 7.98 & 0.63 & 1.00 \\
\hline $\mathrm{T}_{9}$ & 7.90 & 0.73 & 1.28 \\
\hline$T_{10}$ & 8.13 & 1.16 & 1.00 \\
\hline SEd & 0.26 & 0.03 & 0.03 \\
\hline$C D(P=0.05)$ & 0.53 & 0.05 & 0.07 \\
\hline
\end{tabular}

* Pooled mean of three years.

The available $\mathrm{N}$ content was the highest in treatment $\mathrm{T}_{9}$, due to the application of $100 \% \mathrm{NPK}+5 \mathrm{t} \mathrm{ha}^{-1}$ poultry manure followed by $\mathrm{T}_{5}$. This could be due to the addition of $\mathrm{N}$ from both inorganic fertilizer and poultry manure 
which supplied excess $\mathrm{N}$ as compared to FYM (Table 5). These findings are in accordance with the findings of Yadav et al., (2010).

Highest available $P$ was recorded in the treatment $T_{9}$, which was on par with the treatment $T_{10}$. The increase in available $P$ content of soil due to the incorporation of organic manures may be attributed to the direct addition of $P$ as well as solubilization of native $P$ through release of various organic acids. Similar improvement in available $P$ status due to the integrated use of manures and fertilizers has been reported by Sharma et al., (2009).

Table 5: Soil nutrient status of the post harvest soil $\left(\mathrm{kg} \mathrm{ha}^{-1}\right)$.

\begin{tabular}{lccc}
\hline Treatments & $\mathbf{N}^{\boldsymbol{*}}$ & $\mathbf{P}^{\boldsymbol{*}}$ & $\mathbf{K}^{\boldsymbol{*}}$ \\
\hline $\mathrm{T}_{1}$ & 378 & 41.6 & 327 \\
$\mathrm{~T}_{2}$ & 378 & 37.3 & 310 \\
$\mathrm{~T}_{3}$ & 401 & 59.6 & 348 \\
$\mathrm{~T}_{4}$ & 350 & 39.6 & 341 \\
$\mathrm{~T}_{5}$ & 425 & 42.3 & 385 \\
$\mathrm{~T}_{6}$ & 359 & 40.0 & 380 \\
$\mathrm{~T}_{7}$ & 341 & 66.7 & 326 \\
$\mathrm{~T}_{8}$ & 280 & 70.0 & 320 \\
$\mathrm{~T}_{9}$ & 79.7 & 335 \\
$\mathrm{~T}_{10}$ & 406 & 76.3 & 294 \\
\hline $\mathrm{SEd}$ & 350 & 1.75 & 3.60 \\
$\mathrm{CD}(\mathrm{P}=0.05)$ & 4.42 & 3.64 & 7.48 \\
\hline
\end{tabular}

* Pooled mean of three years.

The available $\mathrm{K}$ was the highest in the treatment $T_{5}$, which was found to be on a par with $T_{6}$. The soil nutrient status was enhanced with the poultry manure application since the nutrient contents of this manure were higher. This beneficial effect of organic manure on available $\mathrm{K}$ status was reported by Kumawat and Kumawat (2010).

\section{SUMMERY AND CONCLUSION}

The integrated use of organic manures viz., FYM and poultry manure along with chemical fertilizers increased the yield of hybrid maize and uptake of NPK over sole use of chemical fertilizers. Substantial improvement was recorded in residual soil fertility as the contents of organic carbon, available nitrogen, phosphorus and potassium were significantly higher in the plots that received poultry manure in combination with chemical fertilizers than the plots that received chemical fertilizers. From the treatments effects on yield, nutrient uptake and soil fertility status, It could also be concluded that, the application of poultry manure performed better than FYM owing to its higher nutrient contents.

\section{REFERENCES}

Adeli, A. and J.J. Varco. 2002. Potassium management effects on cotton yield, nutrition, and soil potassium level. J. Plant Nutr. 25(10):22292242.

Crop Production Guide. 2005. Department of Agriculture (Ed.), Government of Tamil Nadu, Chennai, India. 
Datt, N., R.P. Sharma and G.D. Sharma. 2003. Effect of supplementary use of farmyard manure along with chemical fertilizers on productivity and nutrient uptake by vegetable pea (Pisum sativum var arvense) and build up of soil fertility in Lahaul Valley of Himachal Pradesh. Indian J. Agric. Sci. 73(5):266-268.

Jackson, M.L. 1973. Soil Chemical Analysis. Prentice Hall of India Pvt. Ltd., New Delhi, India.

Jaggi, R.C. 2007. Nutritional research in vegetables of Himachal Pradesh. Indian J. Fert. 2(12):25-44.

Kaleeswari, R.K. 2009. Evaluation of soil phosphorus tests and its relation to inorganic $P$ forms in flooded soils. An Asian J. Soil Sci. 4(1):121-124.

Kumawat, B.L. and A. Kumawat. 2010. Dynamics of some soil quality parameters as influenced by amendment of a loamy sand soil with different plant materials and fertilizer nitrogen. J. Indian Soc. Soil Sci. 58(3):336-340.

Lindsay, W.L. and W.A. Norvell. 1978. Development of a DTPA soil test for zinc, iron, manganese, and copper. Soil Sci. Soc. Am. J. 42(3):421428.

Mahimairaja, S., N.S. Bolan and M.J. Hedley. 1995. Dissolution of phosphate rock during the composting of poultry manure: an incubation experiment. Nutr. Cycl. Agroecosystems 40(2):93-104.

Nambiar, K.K.M. and I.P. Abrol. 1989. Long term fertilizer experiments in India (an overview). Fert. News 34(4):11-20.

Olsen, S.R., C.V. Cole, F.S. Watanabe and L.A. Dean. 1954. Estimation of available $P$ in soils by the extraction with sodium bicarbonate. Circ. U.S. Dep. Agric. 939.

Pervez, H., M. Ashraf and M.I. Makhdum. 2004. Influence of potassium rates and sources on seed cotton yield and yield components of some elite cotton cultivars. J. Plant Nutr. 27(7):1295-1317.

Piper, C.S. 1942. Soil and Plant Analysis. Hans Publishers, Bombay, India.

Richards, L.A. 1954. Diagnosis and improvement of saline and alkaline soils. USDA Agriculture Handbook No. 60, U.S. Government Printing office, Washington DC.

Santhy, P., M.S. Velusamy, V. Murugappan and D. Selvi. 1999. Effect of inorganic fertilizers and fertilizer-manure combination on soil physicochemical properties and dynamics of microbial biomass in an Inceptisol. J. Indian Soc. Soil Sci. 47(3):479-482.

Satish Chander and N.K. Tripathi. 2006. Integrated nutrient Management for soil health enhancement. Proc. Fert. Assoc. India (FAl) Seminar 28-30 Nov., pp 3/1-3/10.

Sharma, R.P., A. Sharma and J.K. Sharma. 2005. Productivity, nutrient uptake, soil fertility and economies as affected by chemical fertilizers and farmyard manure in broccoli (Brassica oleracea var italica) in an Entisol. Indian J. Agric. Sci. 75(9):576-579.

Sharma, R.P., D. Naveen and C. Girish. 2009. Effect of vermicompost, farmyard manure and chemical fertilizers on yield, nutrient uptake and soil fertility in okra (Abelmoschus esculentus)-onion (Allium cepa) sequence in wet temperate zone of Himachal Pradesh. J. Indian Soc. Soil Sci. 57(3):357-361. 
Singh, M.V. 2007. Problems of micro and secondary nutrients in acid soils of India and their management. Bull. Indian Soc. Soil Sci. 25:27-58.

Singh, R.N. and R.K. Pathak. 2003. Response of wheat (Triticum aestivum) to integrated nutrition of $\mathrm{K}, \mathrm{Mg}, \mathrm{Zn}, \mathrm{S}$ and biofertilization. J. Indian Soc. Soil Sci. 51(1):56-60.

Sinha, N.P., B. Prasad and A.B. Ghosh. 1981. Effect of continuous use of fertilizers on yield and nutrient uptake in a wheat-soybean-potato cropping system. J. Indian Soc. Soil Sci. 29(4):537-542.

Stanford, G. and L. English. 1949. Use of the flame photometer in rapid soil tests for $\mathrm{K}$ and Ca. Agron. J. 41(9):446-447.

Subbiah, B.V. and G.L. Asija. 1956. A rapid procedure for the estimation of available nitrogen in soils. Curr. Sci. 25(8):259-260.

Walkley, A. and I.A. Black. 1934. An examination of the degtjareff method for determining soil organic matter, and a proposed modification of the chromic acid titration method. Soil Sci. 37(1):29-38.

Yadav, P.C., A.C. Sadhu, P.K. Swarnkar and M.R. Patel. 2010. Effect of integrated nitrogen management on forage yield of multicut sorghum, available nitrogen and microbial count in the soil. J. Indian Soc. Soil Sci. 58(3):303-308.

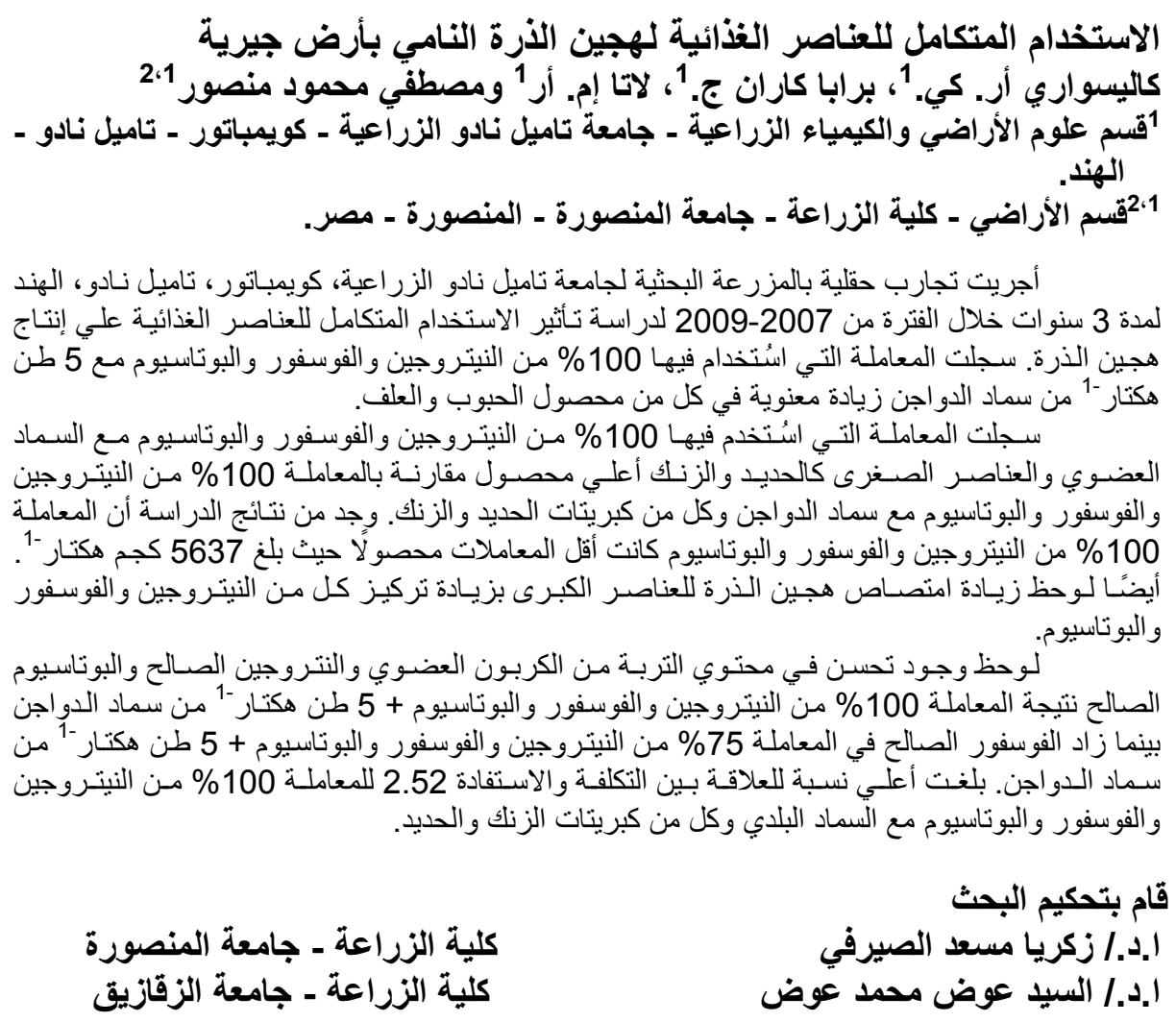

